\title{
Alergija lateksui
}

\author{
Laura Žilinskaitè, Brigita Šitkauskienè \\ LSMU MA Pulmonologijos ir imunologijos klinika
}

Reikšminiai žodžiai: lateksas, alergija, isijautrinimas, medicinos darbuotojai.

Santrauka. Pradejjus plačiai naudoti lateksą, per pastaruosius 25 metus padaugèjo su lgE susijusių alerginių reakcijų. Isijautrinimas lateksui bendrojoje populiacijoje gana nedidelis (1-2 proc.), tačiau dažnai diagnozuojamas tam tikrų profesiju atstovams (medicinos darbuotojams, žmonėms, dirbantiems kaučiuko pramonejje). Itin didelis šios alergijos pavojus gresia dirbantiems operacinèse, laboratorijose ir hemodializès centruose. Didelès rizikos grupei priskiriami ir pacientai, turintys ¡¡skilą stuburą, patyrę daug chirurginių procedūrų, sergantys atopija, rankų dermatitu ar egzema, alergiški vaisiams bei daržovėms. Reakciju patogenezinis mechanizmas gali būti j̨vairus: I tipo hipererginės, IV tipo lètosios arba neimuninès kilmės reakcijos. Alergijos lateksui simptomai įvairūs: nuo odos pažeidimo iki anafilaksinio šoko. Šio straipsnio tikslas apžvelgti alerginių reakcijų lateksui išsivystymo mechanizmus, jų klinikinę raišką, rizikos veiksnius, pateikti diagnostikos ir gydymo metodus, epidemiologinius duomenis.

Lateksas - tai pieną primenantis skystis, gaminamas iš kaučiuko medžio Hevea brasiliensis, ore koaguliuoja [1, $2,3,4]$. Pradejus plačiai naudoti lateksą, per pastaruosius 25 metus padaugèjo su IgE susijusių alerginių reakcijų i šią medžiagą [5]. Pirmą kartą hipererginès reakcijos ị lateksą literatūroje aprašytos $1979 \mathrm{~m}$. Būtent tada šių reakcijų padaugejo, nes vis dažniau imtos naudoti latekso pirštinès $[1,5]$, o apie $1980 \mathrm{~m}$. ženkliai padaugèjo alerginių reakcijų i natūralaus kaučiuko lateksą [6]. Isijautrinimas lateksui bendrojoje populiacijoje gana nedidelis (1-2 proc.), tačiau dažnai diagnozuojamas tam tikrų profesijų, kurios priskiriamos didelès rizikos grupei, atstovams (medicinos darbuotojams, žmonėms, dirbantiems kaučiuko pramonèje) $[1,7,8]$.

Šio straipsnio tikslas - apžvelgti alerginių reakcijụ lateksui išsivystymo mechanizmus, jų klinikinę raišką, pateikti diagnostikos ir gydymo metodus, epidemiologinius duomenis.

\section{RIZIKOS VEIKSNIAI}

Lateksas plačiai naudojamas medicininių pirštinių gamyboje, todèl didesnès rizikos grupei priklauso medicinos darbuotojai (1 pav.), nuolat darbo aplinkoje tiesiogiai ir netiesiogiai kontaktuojantys su šiuo alergenu. Šios alergijos pavojus itin didelis dirbantiems operacinèse, laboratorijose ir hemodializès centruose $[7,9]$. Taivane natūralaus kaučiuko lateksas yra pagrindinis medicinos darbuotojų alergenas, todèl C. T. Lin, D. Z. Hung su kolegomis atliko tyrimą, kuriuo siekè išsiaiškinti alerginių reakcijų atsiradimo ir įsijautrinimo dažnumą medicinos darbuotoju grupeje. Tyrime dalyvavo 1253 medicinos darbuotojai. Jie buvo apklausti anketiniu būdu. 152 (12 proc.) tiriamiesiems nustatyti teigiami odos dūrio su latekso alergenu mèginiai, o tai reiškia, kad tie asmenys ịsijautrinę lateksui. Kontaktinis dermatitas rankų srityje pastebėtas 35 proc. Teigiamas odos dūrio mėginys dažniau nustatytas asmenims, ilgą laiką naudojusiems lateksą. Šio tyrimo duomenimis, alergija lateksui yra profesinè medicinos darbuotojų

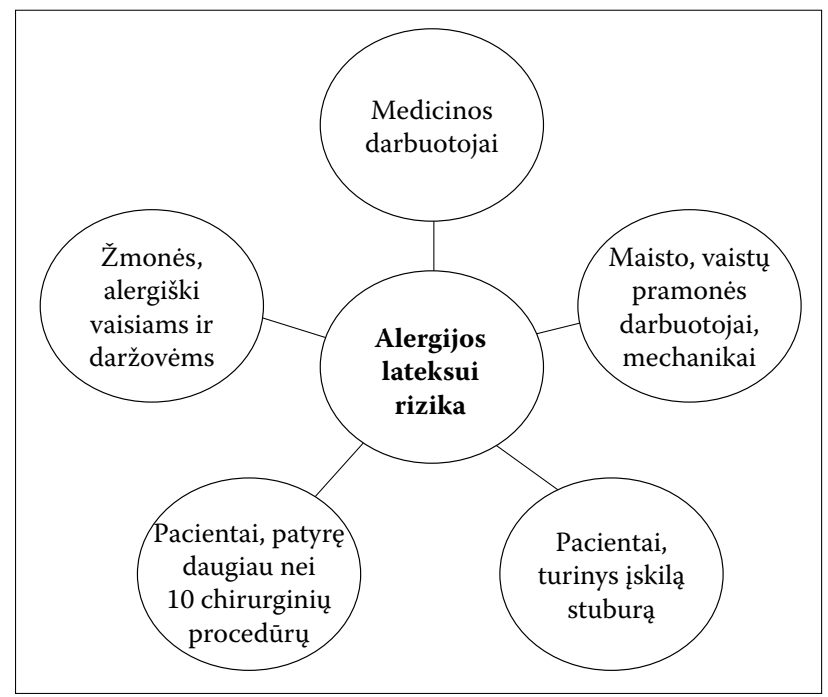

1 pav. Asmenys, kuriems alergijos lateksui rizika yra didžiausia $[1,5,6,7,8,9,10,15]$ 
1 lentelè. Latekso sukeliamos imuninès ir neimuninès reakcijos [1]

\begin{tabular}{|c|c|c|c|}
\hline $\begin{array}{l}\text { Reakcijos } \\
\text { tipas }\end{array}$ & Simptomai & Priežastis & $\begin{array}{l}\text { Pasireiškimo } \\
\text { pradžia }\end{array}$ \\
\hline I tipas & $\begin{array}{l}\text { Dilgèlinè, } \\
\text { pykinimas, } \\
\text { vėmimas, } \\
\text { silpnumas, } \\
\text { rinitas, } \\
\text { konjunktyvitas, } \\
\text { bronchospazmas, } \\
\text { anafilaksinis } \\
\text { šokas }\end{array}$ & Lateksas & $\begin{array}{l}\text { Staiga (per } \\
\text { kelias minutes) }\end{array}$ \\
\hline IV tipas & $\begin{array}{l}\text { Papulès, pūslelès, } \\
\text { pūslès, niežèjimas }\end{array}$ & $\begin{array}{l}\text { Latekso piršti- } \\
\text { niụ cheminès } \\
\text { medžiagos }\end{array}$ & $\begin{array}{l}\text { Užsitęsusi (nuo } \\
\text { kelių valandų } \\
\text { iki } 48 \text { val.) }\end{array}$ \\
\hline $\begin{array}{l}\text { Neimuninès } \\
\text { kilmès }\end{array}$ & $\begin{array}{l}\text { Sausa, suskilusi, } \\
\text { sudirgusi oda }\end{array}$ & $\begin{array}{l}\text { Latekso piršti- } \\
\text { nių cheminès } \\
\text { medžiagos }\end{array}$ & Po kelių dienų \\
\hline
\end{tabular}

liga, rutininis odos dūrio méginys gali parodyti ịsijautrinimą lateksui dar nesant alerginès reakcijos požymių [10]. Dar vienas tyrimas, atliktas F. L. Filo ir R. Cerchi Triesto (Italija) ligoninèse, taip pat patvirtino, jog tarp medicinos darbuotojų alergija ir ịsijautrinimas lateksui pasiktaiko reikšmingai dažniau nei bendrojoje populiacijoje [11]. Dakaro ligoninèse atliktu tyrimu nustatyta, jog 11 proc. tiriamųjų įsijautrinę latekso pirštinėms [12]. Svarbu atkreipti dèmesi ne tik i medicinos darbuotojus, bet ir i kitus žmones, kurie darbo aplinkoje dažnai susiduria su lateksu: maisto, vaistų pramonès darbuotojai, mechanikai [5].

Didelès rizikos grupei priskiriami ir pacientai, turintys i̇skilą stuburą (spina bifida) bei patyrę daug chirurginių procedūrų, nes jų gleivinès kartotinai kontaktuoja su lateksu operacijų ir chirurginiu procedūrų metu $[1,6,8]$. Nustatyta, jog CNS galima lokali IgE gamyba [13]. Alergijos lateksui dažnumas asmenų, turinčių ịskilą stuburą, grupèje - 20-67 proc., tikimybè, kad jiems pasireikš anafilaksinè reakcija operacijos metu, yra 500 kartų didesnè nei kontrolinèse grupèse [1]. Suaugusieji, patyrę daugiau nei 10 operacijų, yra priskiriami rizikos grupei [7]. Alergija lateksui padideja po kiekvienos operacijos [1]. Nustatyta, jog operuojamiems vaikams 76 proc. atveju anafilaksini šoką išprovokuoja latekso alergenas [14]. Suaugusiųjų grupèje latekso sukeltos anafilaksinès reakcijos pasireiškia $12-40$ proc. [1, 7].

Žmonès, alergiški vaisiams ir daržovèms, taip pat priskiriami rizikos grupei $[1,8,15]$. Daugiau nei pusei pacientų, alergiškų lateksui, randama specifinių IgE prieš kai kuriuos maisto produktus [5]. Taip yra todèl, kad lateksas ir vaisiai bei daržovès turi kryžminių alergenų [6]. Dar 1994 m. Ispanijoje C. Blanco, T. Carrillo su kolegomis atliko perspektyvųji tyrimą, kurio metu latekso sukelti alerginiai požymiai (iskaitant ir anafilaksini šoką) pastebėti 36 proc. pacientams, 13 diagnozuota alergija 42 maisto produktams (52 proc.). Dažniausiai alergija išsivysto šiems maisto produktams: avokadui (9), bananui (7), kiviui (5) ir papajai (3). Nustatytos kryžminès reakcijos tarp latekso, avokado ir banano. Šio tyrimo metu išsiaiškinta, jog alergija latek- sui dažniausia didesnès rizikos profesijų vidutinio amžiaus moterims. Taip pat nustatytas ryšys tarp alergijos lateksui ir vaisiams [15]. Kiti alergijos lateksui rizikos veiksniai yra atopija bei buvęs bet kokios kilmès rankų dermatitas ar egzema, nes pro sausą, suskilusią odą lateksas lengviau prasiskverbia [1, 12].

\section{PATOGENEZINIAI MECHANIZMAI IR KLINIKINIAI POŽYMIAI}

Alerginių reakcijų i latekso alergeną patogenezinis mechanizmas gali būti ịvairus: dažniausios IV tipo lètosios reakcijos (pvz., kontaktinis dermatitas), I tipo reakcijos (dilgėlinè, bronchospazmas, anafilaksinis šokas) arba neimuninès kilmès [1]. I tipo hipererginès reakcijos yra imuninès, susijusios su IgE atsaku ị latekso proteinus, pasireiškia greitai ir sukelia ịvairius simptomus: nuo dilgèlinès iki anafilaksinio šoko. Jų metu latekso alergenai susijungia su IgE, kurie yra prisitvirtinę ant bazofilų. Sąveikos metu iš bazofilų išsiskiria mediatoriai (histaminas, triptazè, leukotrienai, prostaglandinai, TNF- $\alpha$ ), greitai sukeliantys klinikinius simptomus [14]. Dažniausiai tokio tipo reakcija nustatoma pacientams, kuriems po kontakto su latekso pirštinėmis iškart pastebima odos pokyčių. IV tipo reakcijos išsivysto dèl cheminių medžiagų, katalizatorių ir antioksidantų, esančių pirštinių sudètyje, bet labai retai nuo paties latekso, jos yra uždelstos - išryškejja praejjus parai ar dviem po kontakto. Tai ląstelinio tipo reakcijos, jų metu svarbiausią vaidmeni atlieka $\mathrm{T}$ limfocitai [14]. Kliniškai pastebimos papulès, pūslelès, pūslès, niežèjimas. Neimuninès reakcijos atsiranda dèl tiesioginio latekso poveikio odai. Tokiais atvejais pacientai skundžiasi sausa, sutrūkusia, sudirgusia oda, simptomai išryškejja po kelių dienų. Jų išsivystymo mechanizme nedalyvauja imuninès sistemos komponentai (1 lentelè) [1].

Kliniškai alergija lateksui gali pasireikšti ne tik odos simptomais (dilgèline ir angioedema), bet ir apatinių ir viršutinių kvėpavimo takų pažeidimu (rinokonjunktyvitu, astma ir gerklų edema) bei širdies ir kraujagyslių sistemos sutrikimais. Anafilaksinio šoko tikimybè didesnẻ intervencinių procedūrų metu [5, 8]. Pagal tyrimo, atlikto Triesto (Italija) ligoninèje, ir literatūros analizès duomenis dažniausiai alergija lateksui pasireiškia dilgèline, rinokonjunktyvitu ir astma (4-5, 6 proc.) [11]. Dakaro ligoninès tyrimu nustatyta, kad iš 140 anketiniu būdu apklaustų sveikatos priežiūros darbuotojų, savo darbe naudojančiuc latekso pirštines, dilgèlinė ir staigus niežèjimas pasireiškė 8 asmenims, kontaktinis dermatitas kartu su dilgèline -2 , alerginis konjunktyvitas -1 , alerginis rinitas -1 , astma -2 , kontaktinis dermatitas - 6 [12].

\section{DIAGNOSTIKOS GALIMYBE்S}

Alergija lateksui diagnozuojama išsiaiškinus anamnezę bei atlikus specialius tyrimus, kurie parenkami pagal vyraujančius klinikinius simptomus: odos dūrio mėgini, odos lopo mėginị, pirštinių provokacinį mėginį, ištyrus lateksui specifinių serumo IgE koncentraciją (2 pav.). 
Siekiant išvengti anafilaksinio šoko chirurginès procedūros metu, prieš operaciją pacientai turètų užpildyti anketą apie alergijos lateksui simptomus. Renkant anamnezę, reikia paklausti pacientų, ypač atopiškų, apie odos ir kvejpavimo sistemos simptomus, taip pat apie alergiją maistui. Svarbu nustatyti, ar reakcija yra imuninès ar neimuninès kilmés, nes nuo to priklauso gydymo sėkmé [1]. Remiantis vien tik anamneze ir paciento nusiskundimais, negalima tiksliai nuspręsti, ar simptomai pasireiškia dèl imuninio atsako. Italijos Bario universitete 2002 $\mathrm{m}$. atlikto tyrimo duomenimis, tik 9 proc. iš medicinos darbuotojų, teigiančių, kad yra alergiški lateksui, iš tiesų buvo jam alergiški [16]. Vokietijoje $2002 \mathrm{~m}$. apklausus odontologijos studentus, 10 proc. teigè, jog yra alergiški lateksui, bet tik 1 proc. buvo patvirtintas ìsijautrinimas atlikus odos dūrio mégini [17].

Visuotiné profilaktinė patikra atliekant laboratorinius tyrimus prieš operaciją nèra rekomenduojama. Tyrimai atliekami tik minètuc rizikos grupių atstovams. Nèra standartizuoto protokolo, kaip reikètų diagnozuoti ìsijautrinimą lateksui. Pirmiausia siūloma atlikti odos dūrio méginius. Specifinių serumo IgE koncentracijos nustatymas rekomenduojamas esant anafilaksinio šoko rizikai bei nesant galimybès atlikti odos dūrio mèginių [7]. Šio tyrimo jautrumas svyruoja nuo 50 iki 90 proc., o specifiškumas - 80-87 proc. [7]. Padidejusi IgE koncentracija gali išlikti iki penkerių metu po latekso ekspozicijos [1]. Pirštinių provokacinis mėginys atliekamas tada, kai klinikiniai požymiai ir IgE koncentracijos tyrimo rezultatai nesutampa. Testo metu pacientas mūvi latekso pirštinę ant vieno piršto, jei po $15 \mathrm{~min}$. dilgẻlinès požymių nematyti, didinamas sąlyčio plotas (latekso pirštinè maunama ant kelių pirštų). Tyrimas baigiamas, kai atsiranda dilgèlinès simptomu (teigiamas rezultatas) arba kai pacientas gali mūvèti pirštinę ant visos rankos nesant alergijos simptomų $15 \mathrm{~min}$. (neigiamas rezultatas). Odos lopo méginiai naudojami IV tipo odos reakcijoms nustatyti. Alergeno méginiai uždedami ant odos ir uždengiami pleistru, odos reakcija vertinama po 30 min., 24 val., 48 val. [1, 7].

Romos universitete Università Cattolica del Sacro Cuore buvo atliktas tyrimas, kurio metu 40 suaugusiujų, patyrusių su latekso naudojimu susijusias alergines reakcijas, kurios patvirtintos odos dūrio mèginiu ar specifinių IgE tyrimu, ir 20 kontrolinès grupès asmenų buvo atlikti provokaciniai mėginiai su latekso alergenu (odos, geriamasis - gleivinių, poliežuvinis, per junginę, pro nosit, pro bronchus ir makštinis). Visi pacientai reagavo ị bent vieną iš šių tyrimų: odos, nosies ir junginès provokacinị mėginį. Anafilaksinių reakcijų nepastebėta. Makštinis provokacinis mėginys su latekso alergenu pasirodè esąs saugiausias, bet mažo jautrumo, ji sudètingiau atlikti. Bronchų ir nosies provokaciniai mėginiai su latekso alergenu buvo patys jautriausi (atitinkamai 76 proc. ir 82 proc.) ir tikslesni nei kiti méginiai, o bronchu provokacinis mejginys su latekso alergenu - pats rizikingiausias. Gleivinių ir odos provokaciniai mėginiai su latekso alergenu pasirodè esantys specifiškiausi. Tyrimas rodo, kad provokaciniai mėginiai yra pakankamai saugūs, ir juos galima naudoti diagnostikos tikslais [18].

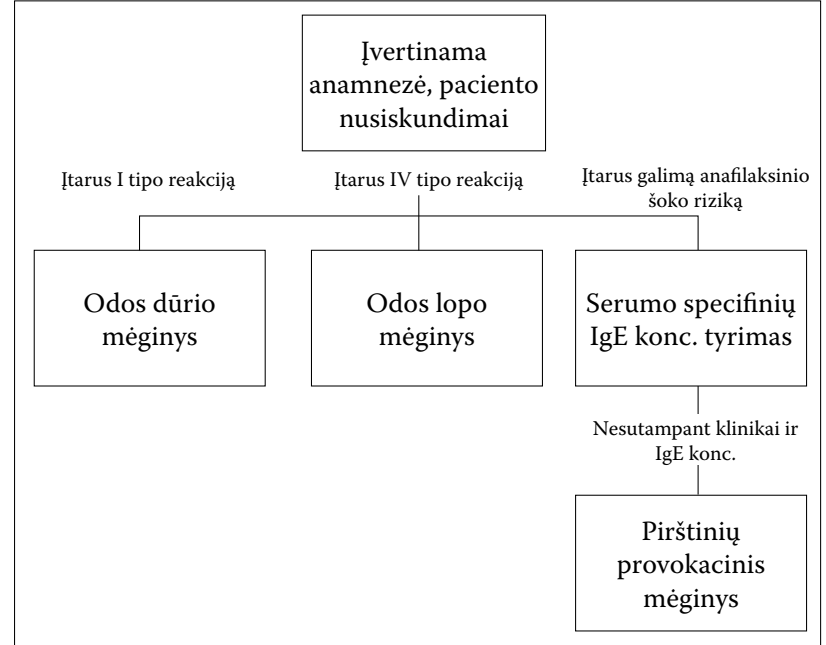

2 pav. Alergijos lateksui diagnostikos algoritmas [1, 7]

\section{GYDYMAS IR PROFILAKTIKA}

Alergijos lateksui gydymas susideda iš dviejų pagrindinių etapu: latekso alergeno vengimo ir simptominio gydymo. Padidejus pirštinių be latekso arba su mažiau latekso naudojimui, sumažejo medicinos darbuotoju alergijos lateksui dažnumas [1]. F. L. Fillon ir R. Cerchi Italijoje atliktas tyrimas parodè, jog simptomai silpnejja ir įsijautrinimo dažnumas mažeja, pakeitus latekso pirštines su talko milteliais i latekso pirštines be miltelių ir retinant pirštinių naudojimą. Šio tyrimo išvados: pirštinių be talko miltelių naudojimas gali sumažinti simptomus ir sustabdyti įsijautrinimą [11]. Tai patvirtina ir Vokietijoje atliktas tyrimas su odontologijos studentais: naudojantiems latekso pirštines be talko miltelių rečiau pasireiškẻ alergijos simptomų [17]. İskilą stuburą turinčių vaikų alergijos lateksui dažnumas sumažèjo, kai buvo pradètos gaminti pirštinès be talko miltelių, o vèliau - pirštinès be latekso [13]. Vis dèlto geriausia išeitis naudoti pirštines, pagamintas ne iš latekso $[1,11]$. Buityje latekso pirštinès turètų būti visiškai nenaudojamos [5].

Naujausių tyrimų duomenys rodo, jog îskilą stuburą turinčių vaikų, nuo vaikystès augusių visiškai be sąlyčio su lateksu, ịsijautrinimas jam bei klinikiniai alergijos požymiai reikšmingai sumažèjo, o įsijautrinimas inhaliuojamiesiems alergenams bei alerginių ligų pasireiškimas pasiekė bendrosios populiacijos rodiklius. Potencialūs alergenai (tokie kaip lateksas) gali sukelti įsijautrinimo progresavimą didelès rizikos grupių atstovams (pvz., vaikams su įskilu stuburu), ir tik visiška apsauga nuo šių alergenų gali sustabdyti alergijos vystymąsi. Taigi, vengti alergeno - labai efektyvus būdas sustabdyti issijautrinimo progresavimą. Šie nauji duomenys nutraukia vykusias diskusijas, ar įskilą stuburą turintys pacientai paveldi alergijos lateksui riziką, ir įrodo, jog daugkartinès chirurginès procedūros gali būti atliekamos, taikant profilaktikos priemones [13]. İskilas stuburas dažniausiai nustatomas dar vaisiui esant gimdoje arba iškart po gimimo, taigi galima iškart vengti latekso alergenų ir sustiprinti pirminès profilaktikos veiksmingumą $[1,6]$.

Pacientai turi žinoti, kurių produktų sudètyje yra latekso, taip pat maisto produktus, kurie sukelia kryžmines reakcijas, ir jų vengti [1]. Pagrindinis uždavinys - suma- 
2 lentelè. Simptominis alergijos lateksui gydymas [1]

\begin{tabular}{ll}
\hline Simptomai & Gydymas \\
\hline $\begin{array}{l}\text { Lokalus kontaktinis } \\
\text { dermatitas }\end{array}$ & Vietinio poveikio gliukokortikoidai \\
\hline $\begin{array}{l}\text { Išplitęs kontaktinis } \\
\text { dermatitas }\end{array}$ & Sisteminio poveikio gliukokortikoidai \\
\hline Dilgėlinė ir niežèjimas & Antihistamininiai vaistai \\
\hline Bronchospazmas & Bronchodilatatoriai \\
\hline Anafilaksinis šokas & $\begin{array}{l}\text { Paciento kvėpavimo takų praeinamumo } \\
\text { užtikrinimas, širdies ir kraujagyslių siste- } \\
\text { mos funkcijų sureguliavimas, deguonies } \\
\text { tiekimas, elektrolitų ir skysčių pusiausvy- } \\
\text { ros atkūrimas, adrenalinas ị veną }\end{array}$ \\
\hline
\end{tabular}

žinti latekso pirštinių naudojimą. Tai jau iš dalies pasiekta didelèse Vakarų šalių ligoninėse. Tačiau keičiantis latekso alergijos demografinei statistikai ir plintant technologinei revoliucijai, manoma, kad Kinijoje, Indijoje kils antroji alergijos lateksui banga. Natūralaus kaučiuko lateksas pasižymi tąsumu, elastingumu ir pakankamu tvirtumu, todèl labai sunku pagaminti kokybišką alternatyvią medžiagą [6].

Asmenys, patyrę sunkią I tipo alerginę reakciją, tie, kuriems lateksas sukelia sistemines reakcijas, turètų su savimi nešiotis adrenalino švirkštą, kurio prireiktų, jei ištiktų anafilaksinis šokas. Lateksui alergiški asmenys turètų žinoti, jog maistas, paruoštas naudojant latekso pirštines, irgi gali išprovokuoti alergijos simptomus [1].

Lokalūs kontaktinio dermatito simptomai gydomi vietinio poveikio gliukokortikoidų tepalais, o pažeidimams išplitus šie hormonai vartojami sistemiškai (2 lentelè). Antihistamininiai preparatai skiriami dilgèlinès simptomams ir niežejjimui palengvinti. Bronchodilatatorių vartojama esant bronchospazmui. Anafilaksinio šoko atveju svarbu užtikrinti paciento kvẻpavimo takų praeinamumą, sureguliuoti širdies ir kraujagyslių sistemos funkcijas, jei reikia, tiekti deguonị, atkurti elektrolitu ir skysčių pusiausvyrą, nedelsiant suleisti adrenalino. Svarbu nepamiršti gaivinant pacientą nenaudoti latekso turinčių produktų.

Atsitiktinių imčių klinikinių tyrimų duomenimis, poliežuvinė imunoterapija latekso alergenais efektyvi pacientų, turinčių sunkią alergiją ir negalinčių išvengti latekso savo aplinkoje, gydymui [1]. Specifinę imunoterapiją rekomenduojama taikyti tik mažai daliai asmenų, t. y. darbuotojams, kurie savo darbo aplinkoje neišvengiamai kontaktuoja su lateksu (ne tik tiesiogiai, bet ir kai latekso dalelès sklando ore), ir negydomi jie negalètú dirbti [5]. Atlikus bandymus su poodinès ir poliežuvinès imunoterapijos metodais alergijai lateksui gydyti, nustatyta, jog tai veiksmingas gydymas, bet yra didelè nepageidaujamų reiškinių tikimybė [6]. Dabar pradèti kurti saugesni rekombinantiniai latekso alergenai, kurie sukelia mažiau šalutinių reakcijų, todèl ateityje juos tikimasi taikyti imunoterapijoje [5].

\section{MEDIKŲ ŽINIOS APIE ALERGIJĄ LATEKSUI}

Nors informacijos apie alergiją lateksui galima rasti vis daugiau (yra atliekami ịvairūs tyrimai, kurių rezultatai prieinami visuomenei), tačiau reali rizika ne visada tinkamai suvokiama. Ankaros (Turkija) universitete buvo atliktas tyrimas, kurio tikslas - įvertinti šešto kurso medicinos studentų žinias apie alergiją lateksui ir išsiaiškinti, kokia šios alergijos išsivystymo rizika jiems patiems. 220 šešto kurso studentų užpildè anketas, kuriose buvo pateikti klausimai, padedantys įvertinti pagrindines žinias apie alergiją lateksui, taip pat su šia alergija susijusius simptomus ir kontakto su lateksu trukmę. Jiems buvo atlikti ir odos dūrio mėginiai su latekso alergenu. 44 proc. studentú teisingai atsakè i klausimus apie lateksą. Bent vieną iš latekso pagamintą produktą, naudojamą ne ligonineje, teisingai nurodè 55,5 proc., o produktą, naudojamą ligoninejje, - 95,5 proc. Nustačius alergijos lateksui individualią riziką, apklausti studentai nurodè, kad jos nepaisytų ir vis tiek rinktųsi mediko specialybę. Sis tyrimas parodè, jog paskutinio kurso medicinos studentai labai mažai žino apie alergiją lateksui, o tai kelia didelę riziką jai išsivystyti [19].

Švedijoje atlikus anketini tyrimą, kuriuo siekta išsiaiškinti slaugytojų žinias apie natūralaus kaučiuko lateksą ir alergiją jam, paaiškejjo, jog slaugytojams taip pat nepakanka žinių apie šią alergijos formą [20].

Nors žinoma, jog alergija lateksui yra antra perioperacinio anafilaksinio šoko priežastis, Meksikoje atliktas tyrimas, parodè, jog anesteziologai turi per mažai žinių apie alergijos lateksui simptomus, diagnostiką ir gydymą [21].

\section{PREZERVATYVŲ NAUDOJIMAS, KAI YRA ALERGIJA LATEKSUI}

Vyriški prezervatyvai gaminami iš latekso, todèl tai opi problema tiems, kurie yra alergiški lateksui ir nori pasirinkti būtent ši kontracepcijos būdą. Nuo $1990 \mathrm{~m}$. pradèti gaminti prezervatyvai iš poliuretano, arba sintetinių elastomerų. Jie skirti vyrams, įsijautrinusiems lateksui, tiems, kuriems jau pasireiškè alergijos simptomai. JAV mokslininkai M. F. Gallo, D. A. Grimes su kolegomis atliko tyrimą, kurio tikslas - ivertinti ir palyginti prezervatyvu be latekso ir prezervatyvu su lateksu kontraceptinị efektyvumą, tvirtumą, vartotojų požiūrị (kuris prezervatyvas jiems labiau patinka). Tyrimu nustatyta, kad prezervatyvai be latekso dažniau plyšta, palyginti su latekso prezervatyvais, tačiau vartotojams apsisaugojimo priemonès be latekso patiko labiau. Kontraceptini efektyvumą dar reikètų tirti, nes vienu tyrimų duomenimis, prezervatyvai be latekso nuo nepageidaujamo néštumo apsaugo silpniau, kitų - kad abiejų rūšių prezervatyvai apsaugo panašiai. Vis dèlto galima daryti išvadą, kad alergiški ar ịsijautrinę lateksui asmenys gali naudoti prezervatyvus be latekso [22].

Latekso prezervatyvai gali sukelti alerginị kontaktini dermatitą. Gerejjant visuomenès švietimui, vis daugiau žmonių naudoja prezervatyvus, noredami apsisaugoti nuo lytiškai plintančių ligų ir nepageidaujamo nėštumo, dèl to daugèja alerginio kontaktinio dermatito atvejų. Todèl labai svarbu tinkamai informuoti vartotojus bei gydytojus, kokios medžiagos įeina i prezervatyvų sudètị. JAV buvo atliktas tyrimas, kurio tikslas - ivertinti, kokiais būdais prezervatyvu gamintojai pateikia infor- 
maciją apie šio produkto alergenus sveikatos priežiūros specialistams. Rezultatai parodè, kad prezervatyvu gamintojai gydytojams pateikia pakankamai informacijos apie medžiagas, ieinančias i produkto sudetit, kurios gali sukelti alergiją [23].

Alerginès reakcijos, atsirandančios panaudojus prezervatyvą, gali būti susijusios ne tik su lateksu, bet ir su kitomis sudettyje esančiomis medžiagomis. Benzokainas, esantis prezervatyvu sudètyje, gali sukelti dermatitą moterų ir vyru lyties organų srityse [24]. Vyrams dèl benzokaino poveikio gali išsivystyti balanitas [25]. Italijos Bario universitete aprašytas 42 metu vyro, kuriam po prezervatyvo panaudojimo išsivystè egzema genitalijų srityje, klinikinis atvejis. Paciento ligos istorijoje nebuvo atopijos simptomų. Egzema vyrui išryškejjo praejjus keletui valandų po prezervatyvo su lytini aktą prailginančiu kremu naudojimo. Odos lopo mèginys patvirtino stiprią alerginę reakciją i benzokaino ir parabeno mišinị, esantị kremo sudètyje [26]. Asmenys, alergiški vietinio poveikio anestetikams, negali naudoti prezervatyvų, prailginančių lytinị aktą.

\section{APIBENDRINIMAS}

Bendrojoje populiacijoje alergija lateksui nedažna, tačiau yra rizikos grupių, kuriu atstovams ši alergija išsivyto dažnai: medicinos darbuotojai, žmonès, patyrę daug chirurginių procedūrų, bet kokios kilmès dermatitą, vaikai su įskilu stuburu, atopiški pacientai, alergiški vaisiams ir daržovėms. Tyrimai, apžvelgti šiame straipsnyje, rodo, kad alergija lateksui dažna tarp medicinos darbuotojų bei susijusi su latekso pirštinių naudojimu. Irodymais paremtas ir kryžminių reakcijų tarp latekso ir kai kurių vaisių bei daržovių atsiradimas. Reikètu pabrèžti, jog alergija lateksui išsivysto ne tik tiesiogiai kontaktuojant su alergenu, bet ir būnant aplinkoje, kurioje alergenų koncentracija viršija saugią normą. Taip organizmas įsijautrina, o vèliau gali pasireikšti klinikiniai alergijos simptomai.

Kita opi problema - alergija prezervatyvams, kuri gali išsivystyti tiek dèl latekso alergenų, tiek dèl kitų sudedamụjų medžiagu poveikio. Nors yra gaminami ir naudojami prezervatyvai be latekso, tikslių duomenų apie jų patikimumą nèra, be to, pastebėta, jog jie dažniau plyšta.

Alergija lateksui pasireiškia įvairiai, tai lemia skirtingas patogenezinis mechanizmas. Vis delto dažniausiai alergijos lateksui simptomai atsiranda dèl IgE perteklinès gamybos. Tyrimų duomenimis, dažniausiai paste-

\section{LITERATŨRA}

1. Pollart S. M., Warniment C., Mori T. Latex Allergy. Am Fam Physician 2009; 80 (12): 1413-1418.

2. Heitz J. W., Bader S. O. An evidence-based approach to medication preparation for the surgical patient at risk for latex allergy: is it time to stop being stopper poppers? Journal of Clinical Anesthesia 2010; 22: 477-483.

3. Lstex, internetinè prieiga http://wordnetweb.princeton.edu/perl/ webwn?s=latex

4. Latex, internetinè prieiga http://www.thefreedictionary.com/latex.

5. Marcer G., Gemignani C., Coco G. Natural latex allergy. Patient management: from clinic to prevention. A review. Med Lav 2008; 99 (2): 113-117.

6. Rolland J. M., O'Hehir R. E. Latex allergy: a model for therapy. Clin Exp Allergy 2008; 38 (6): 898-912. bima dilgèlinè, rinokonjunktyvitas, dermatitas, kontaktinis dermatitas. Anafilaksinio šoko tikimybė padidèja kartotinių chirurginių procedūruc metu. Alergija lateksui diagnozuojama kaip ir alergija bet kuriai kitai medžiagai: įvertinami nusiskundimai, anamnezè, klinikiniai požymiai. İtarus, kokio tipo yra reakcija (I, IV tipo ar neimuninès kilmès), diagnozei patikslinti pasirenkamas odos dūrio mėginys, serumo specifinių IgE koncentracijos tyrimas ar odos lopo méginys. Jei klinikiniai požymiai nesutampa su IgE koncentracija, atliekamas provokacinis mėginys su latekso pirštinèmis. Gydymas pradedamas produktu, kuriuose yra latekso, nenaudojimu bei skiriamas simptominis gydymas. Vengti latekso - pati efektyviausia profilaktikos priemonè rizikos grupių atstovams, užkertanti kelią alergijos vystymuisi. Nenaudojant latekso, alergijos požymiai visiškai išnyksta. Tačiau yra tam tikros grupès žmonių, kurie negali išvengti latekso alergenų. Tai asmenys, kurių darbo aplinkoje yra daiktų, pagamintų iš latekso. Ši problema ypač aktuali ligoninėse, kur latekso pirštinių naudojimas labai paplitęs. Todèl atliekami tyrimai, skirti ìvertinti imunoterapijos latekso alergenais naudą. Siūloma, kad šis gydymas būtų taikomas tik tiems žmonèms, kurie niekaip negali išvengti latekso savo aplinkoje. Vis dèlto kol kas stokojama patikimų įrodymų dèl šio gydymo metodo efektyvumo bei nepageidaujamų reakcijų rizikos.

\section{LATEX ALLERGY}

\section{LAURA ŽILINSKAITE், BRIGITA ŠITKAUSKIENE் DEPARTMENT OF PULMONOLOGY AND IMMUNOLOGY LITHUANIAN UNIVERSITY OF HEALTH SCIENCE}

Keyword: latex, allergy, hypersensitivity, health care workers. Summary. The widespread use of latex products in the last 25 years increases lgE mediated sensitization. The incidence of latex allergy in the general population is 1-2 proc., but latex allergy is often diagnosed for certain profession people (health care workers, people working in rubber industry). Particularly high risk to develop latex allergy is for those who work in operating rooms, laboratories and haemodialysis centres. Risk factors for latex allergy include patients with spina bifida, those who have multiple surgeries, atopy, previous hand dermatitis or eczema and patients who have allergy to vegetables and fruits. Pathogenesis of latex allergy can be I type immediate reaction, IV type delayed reaction and non-immune response. This determines what kind of symptoms appear. Clinical manifestation differs from skin reactions to anaphylactic shock. The aim of this article is to review mechanisms of development of latex allergy, its clinical manifestation and risk factors, methods of diagnostics and treatment and epidemiological data.

7. Taylor J. S., Erkek E. Latex allergy: diagnosis and management. Dermatol Ther 2004; 17 (4): 289-301.

8. Anda M., Gómez B., Lasa E., Arroabarren E., Garrido S., Echechipía S. Latex allergy. Clinical manifestations in the general population and reactivity crossed with foodstuffs. An Sist Sanit Navar 2003; 26 (2): 75-80.

9. Wakelin S. H., White I. R. Natural rubber latex allergy. Clin Exp Dermatol 1999; 24 (4): 245-248.

10. Lin C. T., Hung D. Z., Chen D. Y. et al. A hospital-based screening study of latex allergy and latex sensitization among medical workers in Taiwan. J Microbiol Immunol Infect 2008; 41 (6): 499-506.

11. Filon F. L., Cerchi R. Epidemiology of latex allergy in healthcare workers. Med Lav 2008; 99 (2): 108-112. 